\title{
Die veelkantige nawerking van Luther in Halle- Wittenberg: 'n Leksikografiese bydrae tot Reformasie 500 oor August Hermann Francke en Paul Tillich
}

\begin{tabular}{|c|c|}
\hline \multicolumn{2}{|c|}{$\begin{array}{l}\text { Authors: } \\
\text { Ignatius W.C. (Natie) } \\
\text { Van Wyk }{ }^{1} \\
\text { Elritia le Roux }{ }^{2}\end{array}$} \\
\hline \multicolumn{2}{|c|}{$\begin{array}{l}\text { Affiliations: } \\
\text { 'Department Church History } \\
\text { and Church Polity, Faculty of } \\
\text { Theology, University of } \\
\text { Pretoria, South Africa }\end{array}$} \\
\hline \multicolumn{2}{|c|}{$\begin{array}{l}\text { Department New Testament } \\
\text { Studies, Faculty of Theology, } \\
\text { University of Pretoria, } \\
\text { South Africa }\end{array}$} \\
\hline \multicolumn{2}{|c|}{$\begin{array}{l}\text { Research Project Registration: } \\
\text { Project Leader: W.A. Dreyer } \\
\text { Project Number: } 77370920\end{array}$} \\
\hline \multicolumn{2}{|c|}{$\begin{array}{l}\text { Description: } \\
\text { Prof. Natie van Wyk is } \\
\text { participating in the research } \\
\text { project, 'History of the } \\
\text { Netherdutch Reformed } \\
\text { Church/Geskiedenis van die } \\
\text { Nederduitsch Hervormde } \\
\text { Kerk', directed by Dr Wim } \\
\text { Dreyer, Department of } \\
\text { Church History and Church } \\
\text { Polity, Faculty of Theology, } \\
\text { University of Pretoria. }\end{array}$} \\
\hline \multicolumn{2}{|c|}{$\begin{array}{l}\text { Corresponding author: } \\
\text { Natie van Wyk, } \\
\text { hto@mweb.co.za }\end{array}$} \\
\hline \multicolumn{2}{|c|}{$\begin{array}{l}\text { Dates: } \\
\text { Received: } 16 \text { May } 2017 \\
\text { Accepted: } 15 \text { July } 2017 \\
\text { Published: } 22 \text { Sept. } 2017\end{array}$} \\
\hline \multicolumn{2}{|l|}{ Read online: } \\
\hline 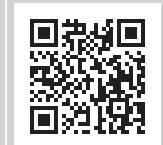 & $\begin{array}{l}\text { Scan this QR } \\
\text { code with your } \\
\text { smart phone or } \\
\text { mobile device } \\
\text { to read online. }\end{array}$ \\
\hline
\end{tabular}

The article is a lexicographic contribution to Reformation 500. Two relatively unknown Lutheran theologians to the South African public, namely August Francke and Paul Tillich, are presented here. Both were students and lecturers at the Martin Luther University of HalleWittenberg. Both of them wanted to be known as Lutheran theologians. The two are totally opposites. Francke was a practical theologian who initiated many diaconal projects that are still active after 300 years. Tillich was a philosopher of religion and a systematic theologian. He made a huge contribution in promoting Lutheran ideas to secular society in the United States of America.

\section{Inleidend}

Martin Luther se teologie het interessante nawerkinge. Teoloë van uiteenlopende denkrigtings beroep hulle op Luther. Dit is veral die Martin-Luther-Universität Halle-Wittenberg wat daarop kan roem dat hy alumni opgelewer het wat teologies ver van mekaar staan. Naas Friedrich Schleiermacher, is August Francke en Paul Tillich die mees bekende produkte van hierdie beroemde universiteit. In hierdie artikel word die lewe en werk van Francke en Tillich onder die aandag gebring. Francke en Tillich word nie alleenlik geroem as uitstaande produkte van hierdie universiteit nie, maar ook as invloedryke Protestantse persoonlikhede. Francke was 'n filoloog en praktiese teoloog met 'n enorme diakonale nalatenskap. In die ingangsportaal van die Fakulteit Teologie in Halle hang skilderye van Francke en Schleiermacher by 'n koper gedenkplaat van Luther. Die Lutherstad Halle is vol herinneringe aan Francke. Naas monumente vind 'n mens straatname en geboue wat na hom vernoem is. Paul Tillich was weer 'n godsdiensfilosoof en sistematiese teoloog wat Luther se sentrale oortuigings, apologeties, aan die moderne wêreld verduidelik het. Hy het op 'n jeugdige ouderdom 'n ere-doktorsgraad van sy alma mater ontvang. Hy het wêreldberoemd geword as dosent in die VSA. Francke en Tillich is totale teenpole, maar juis dít maak die erfenis van Luther so indrukwekkend. Beide hierdie kolosse van die teologiegeskiedenis is onbekend aan die meeste Suid-Afrikaners. Mag hierdie leksikografiese bydrae navorsing oor hierdie twee kinders van Luther stimuleer.

\section{August Hermann Francke (1663-1727) Lewe}

Lewensloop

- 22 Maart 1663 Gebore in Lübeck, Duitsland.

- 1679-1685 Studeer teologie en antieke tale in Erfurt, Kiel, Hamburg en Leipzig.

- 1685 Doktor in die Teologie. Begin met lesings in Filologie in Leipzig.

- 1687 Ontmoet Jakob Spener. Bekering in Lüneburg.

- 1689 Stigting van die Collegium Philobiblicum (Werkgroep vir Bybeluitleg).

- 1690 Predikant en dosent in Diakonaat in Erfurt.

- 1691 Predikant in Halle (St Georgen) en professor vir Grieks en Semitiese Tale in Halle.

- 1694 Huwelik met Anna Magdalena von Wurm. Drie kinders.

- 1695 Stig Skool vir Arm Kinders in Halle.

- 1696 Selfstandigwording van die Weeshuis. Gratis etes vir studente.

- 13 Julie 1698 Hoeksteenlegging van die Weeshuis. Professor in Praktiese Teologie in Halle.

How to cite this article: Van Wyk, I.W.C. \& Le Roux, E., 2017, 'Die veelkantige nawerking van Luther in Halle-Wittenberg:' $n$ Leksikografiese bydrae tot Reformasie 500 oor August Hermann Francke en Paul Tillich', HTS Teologiese Studies/Theological Studies 73(1), a4558. https:// doi.org/10.4102/hts.v73i1.4658

Copyright: ( 2017. The Authors. Licensee: AOSIS. This work is licensed under the Creative Commons Attribution License. 
- 29 April 1701 Inwyding van die Nuwe Weeshuis. Begin drukpers vir Weeshuis.

- 1705 Reis deur Nederland en stel sy gedagtes bekend.

- 1706 Begin met sendingwerk vanuit Denemarke.

- 1707 Stig Fakulteit Opvoedkunde (Seminarium Selectum Praeceptorum) in Halle.

- 21 Oktober 1710 Stigting van die Cansteinischen Bibelanstalt die eerste Bybelgenootskap (Bybeluitgewersmaatskappy) in die wêreld.

- 1725 Stigting van 'n militêre weeshuis in Potsdam.

- 15 Mei 1727 Laaste voorlesing in Halle.

- 8 Junie 1727 Sterf in Halle an der Saale.

\section{Lewensverhaal}

August Hermann Francke is op 22 Maart 1663 in Lübeck, Noord-Duitsland, gebore. Sy pa was 'n juris en sy oupa van moederskant was die burgemeester van hierdie welvarende stad. In 1666 word sy pa na die dorp Gotha beroep om in diens te tree van die Hertog van Sakse - Gotha - Altenburg. In Gotha ontvang hy sy laerskoolopleiding. Van 1679 tot 1685 studeer hy teologie en antieke tale in Erfurt, Kiel, Hamburg en Leipzig. In 1685 behaal hy 'n Magister en 'n Doktorsgraad in Leipzig en begin hy dadelik om dáár filologie te doseer. Twee jaar later ontmoet hy die vader van die Duitse Piëtisme, Jacob Spener, en kom hy tot bekering. In 1689 stig hy 'n 'Gemeenskap vir Bybeluitleg'. Aangesien hierdie groep se werksaamhede as bedreigend vir die Leipzig-Ortodoksie beskou is, word hy uit die stad verdryf. 'n Jaar lank doseer hy Diakonaat in Erfurt. In 1691 word hy egter in Halle aangestel as professor in Grieks en Semitiese Tale. Francke sou in Halle woon en werk, tot sy dood in 1727. Drie jaar na hierdie aanstelling trou hy met Magdalena von Wurm. Die egpaar het drie kinders gehad. In 1695 begin Francke om 'n aantal weeskinders te versorg. Hy stig ook 'n skool vir arm kinders. Een jaar later word die weeskinders in 'n aparte woning geplaas, en op 13 Julie 1698 word die hoeksteen gelê vir 'n weeshuis wat wêreldberoemd sou word. Hy word ook aangestel as professor in Praktiese Teologie. Op 29 April 1701 word 'n nuwe, vergrote weeshuis ingewy, asook 'n drukpers waarmee die weeshuis befonds kon word. Intussen word Francke' $n$ lid van die Society for Promoting Christian Knowledge (SPCK) in Londen en die Berlynse Akademie vir die Wetenskappe. In 1706 begin hy met 'n sendingpoging in Indië deur middel van die Deens-Halle Sendinggenootskap. In 1707 rig hy 'n Fakulteit Opvoedkunde (Seminarium selectum praeceptorum) in Halle op, wat onderwysers kon oplei om in die weeshuisskool en die stadskole Christelike opleiding en opvoeding te verskaf. Op 21 Oktober 1710 word die eerste Bybelgenootskap in die wêreld onder sy leiding gestig, bekend as die Cansteinischen Bibelanstalt. In 1713 besoek koning Friedrich Wilhelm I van Pruise die instellings in Halle en waarborg talle voorregte. In 1725 sou Francke, uit dankbaarheid vir die steun van die koning, in Potsdam 'n militêre weeshuis stig. Francke sterf op 08 Junie 1727 in die ouderdom van 64 jaar. Op 11 Junie word hy in die familiebegraafplaas in Halle begrawe en op 17 Junie vind 'n feestelike roudiens by die Universiteit plaas. Op 22 Julie is daar ook 'n diens by die skole gehou (Obst 2013:71).

\section{Die veelkantige persoonlikheid}

\section{Die teoloog}

Francke word vir baie dinge onthou, soos die oprigting van die weeshuis, opvoedkundige instellings en die eerste Bybelgenootskap. Hy was egter in die eerste instansie 'n teoloog, en wel 'n baie veelsydige teoloog. Sy teologiese denke kan soos volg saamgevat word: God het die weg tot heil bepaal. In die sentrum van die heilsweg staan Jesus Christus en sy verlossingswerk, soos dit in die Bybel betuig word. Alle mense het toegang tot hierdie boodskap. Die mens moet hierdie boodskap egter aanneem. Dít is nie vanselfsprekend nie, aangesien die mens van nature 'n ateïs is. Talle mense weier egter om ateïsties te lewe. God help diesulkes deur sy liefde om 'in die stand van genade te kom'. Hy gebruik siekte, lyding en teenspoed om mense tot omkeer en inkeer te bring. Deur die prediking word die mens opgeroep tot bekering en wedergeboorte, en só word hy 'n nuwe mens wat as kind van God kan lewe. Francke was dus 'n 'bekeringsteoloog'. 'n Bekeringsbelewenis was vir hom voorwaarde vir 'n toegewyde loopbaan in die teologie.

Francke was ook 'n 'Lutherse teoloog'. Hy het vanuit die regverdigingsleer geargumenteer, maar geglo dat geloof aktiewe geloof moet wees - geloof wat deur dade gekenmerk word. Die bekeerling se geloof kan en moet ook groei. Daarvoor is voortdurende gebed en bestudering van die Bybel nodig. Die duiwel en die wêreld bring die bekeerling egter in voortdurende stryd met homself / haarself. Die stryd teen die sonde was vir Francke 'n belangrike saak, aangesien hierdie stryd bydra tot die verbetering van die wêreld. Volgens Francke hoop die bekeringsteoloog altyd op beter tye. Die rede vir hoop het te make met die verandering van die individu deur bekering - wat oorspoel in die verandering van die samelewing. Francke het altyd twee kante van 'n muntstuk beklemtoon. Aan die een kant moet die wedergeborene afstand kry van die wêreld en sy dinge. 'n Binnewêreldse askese is nodig om as bekeerling te volhard. Tóg beteken dit vir Francke aan die ander kant nie wêreldontvlugting en wetenskapsvyandigheid nie. Juis die bekeerling moet 'n bydrae lewer tot radikale maatskaplike hervorming (vgl. Obst 2013:101-106).

Francke was ten diepste 'n Piëtis (vgl. De Groot 1992; Hauschild 1999:689-700). Die Piëtisme wat hy bevorder het, was 'n unieke 'Bybelbeweging'. Bekering, gebed en Christelike moraliteit was onlosmaaklik gekoppel aan die lees en bestudering van die Bybel. Nie die suiwer leer, soos die Ortodoksie beweer nie, maar lewende geloof wat voortspruit uit Bybellees en gebed, is vir Francke konstitutief vir ware kerkwees (Obst 2002:50-54). Hierdie Piëtisme het noodwendig ook tot konflik met ander teoloë en teologiese rigtings gelei.

August Francke is in die teologiegeskiedenis bekend as een van die teoloë wat in konflik gestaan het met die Lutherse Ortodoksie aan die een kant en die Verligting aan die ander kant. Sy bekendste teenstander vanuit die Lutherse Ortodoksie was Ernst Löscher (1673-1749). Löscher was 'n verteenwoordiger van die 'vroom Ortodoksie'. Hy het, ten 
spyte van sy eie vroomheid, Francke daarvan beskuldig dat hy 'vroomheid' tot 'n voorwaarde van ware teologie verhef. Hy het die Piëtisme beskou as 'godsdienstige euwel' wat uitgeroei moet word. Francke het alle kontak met Löscher verbreek. Sy student Joachim Lange (1670-1744), sedert 1709 professor in Halle, het die stryd egter voortgesit. Die bekende graaf Nikolaus Ludwig von Zinzendorf het op 10 Mei 1719 in Merseburg probeer om versoening tussen hierdie twee Lutherse groeperings te bewerkstellig. Hierdie poging misluk, aangesien die afvaardiging uit Halle volgehou het dat ware teologie slegs op bekering en wedergeboorte kan volg. Die Ortodokse afvaardiging uit Leipzig het hierdie vooronderstelling onaanvaarbaar gevind. 'n Eeue lange breuk tussen Halle en Leipzig was die gevolg van hierdie mislukte versoeningspoging (Obst 2002:43-45; 2013:62-64).

Die konflik wat die meeste skade aan Francke en die Piëtisme gedoen het, was dié een met die Verligtingsfilosoof Christian Wolff (1679-1754). Wolff verteenwoordig die gedagte dat etiek en moraal slegs op rasionele argumente gebou mag word. In 'n rektorsrede in 1721 verwerp hy die openbaringsteologiese begronding van die etiek. Sy stelling dat Chinese etiek meer aanvaarbaar is as Christelike etiek, aangesien dit slegs op rasionele argumente staatmaak, het aanleiding gegee tot 'n heftige botsing met Francke. Francke verdedig die oortuiging dat moraal en etiek uitsluitlik afhanklik is van die Bybelse openbaring. Die implikasie is dat sowel Francke as Wolff die totale skeiding van teologie en filosofie bepleit het - dus twee teenoorstaande standpunte aan dieselfde 'Lutherse Universiteit' in Halle. Francke doen 'n beroep op die keiser om in te gryp. Op 03 November 1723 skors Friedrich Wilhelm I vir Wolff as dosent. Ironies genoeg ontvang Wolff 'n professoraat van Marburg, die eerste 'Protestantse Universiteit'. In 1740 beroep Friedrich II Wolff terug na Halle. Hierdie insident het groot en permanente skade aan Francke se reputasie aangerig - en nie net die reputasie van die Piëtisme nie, maar dié van die Christelike teologie as sodanig (Obst 2002:45-46; 2013:65-66).

\section{Die Hervormer}

Volgens Francke is dit nie net die individuele mens wat vernuwe moet word nie, maar die hele wêreld. Met 'wêreld' bedoel Francke die drie 'stande' van sy tyd, naamlik die 'regeerstand', die 'leerstand' en die 'huisstand'. Dit is algemene kennis dat die regeerstand (toe en nou) gekenmerk word deur magsmisbruik en korrupsie. Die leerstand word gekortwiek deur swak en onbekwame dosente en onderwysers, en die huisstand gaan gebuk onder onenigheid, ontrouheid, verwaarlosing en geweld. Volgens Francke is daar net één oplossing: 'Wêreldverandering deur verandering van die individu' (Obst 2013:107). Die regeerstand moet vernuwe word sodat die algemene welwese en die eer van God gedien kan word. Francke dring daarop aan dat die regente na die armes en siekes moet omsien. Hy beveel aan dat die reg toeganklik gemaak moet word vir die gewone burgers en dat die regters die Here moet eerbiedig. Hy dring aan op 'n verbetering van toestande in tronke. Hy stel voor dat omvattende geletterdheidsprogramme onder gevangenes begin moet word. Hy gryp terug op Melanchthon, en dring aan op die hersiening van die hele onderwysstelsel. Van die strafprosedures in skole tot die heropleiding van die leermeesters word aangeraak in sy voorstelle. Vir die hervorming van die huisstand is veral persoonlike bekering nodig. Wie Christus se etiese voorskrifte navolg, sal die huislike omstandighede en verhoudinge verbeter (Obst 2013:106-111).

\section{Die ekumeniese Lutheraan}

Francke het homself verstaan as 'n Lutherse teoloog. Hy het geglo dat hy die Lutherse tradisie op 'n legitieme wyse voortsit. Hy het geglo dat die bewaring van Luther se intensies nie neerkom op die bewaring van die 'ortodokse Lutherse leer' nie, maar uitmond in aktiewe en lewende geloof. Die formele lidmaatskap van die Lutherse Kerk verseker nie heil nie, maar geloof, bekering en wedergeboorte. Hy was egter 'n ekumeniese Lutheraan. Hy was van mening dat Luther se teologiese insigte met die res van die wêreld gedeel moes word. Om hierdie rede het hy hom vir die sending beywer. Sy ideaal was 'n groot, wêreldwye broederskap van wedergebore Lutherane (Obst 2013:111-114).

\section{Die opvoedkundige}

Die teoloog Francke was ook ten diepste pedagoog. Hy het geglo dat teologie en pedagogie bondgenote is. Volgens Francke het alle mense opvoeding nodig, en die beste moontlike opvoeding is 'Christelike opvoeding'. Die hoofdoel van sy teologies-pedagogiese projekte was om mense, en veral kinders, tot geloof te bring. Die Christelike geloof is vir hom die bron van positiewe persoonlike en gemeenskapsontwikkeling. Bekering lei tot die positiewe verandering van die samelewing. Om dít te bereik, moet drie Christelike waardes in die opvoedingsproses gevestig word, naamlik liefde vir die waarheid, gehoorsaamheid en hardwerkendheid. Op grond van hierdie waardes het Francke 'n reuse bydrae gelewer tot die Pruisiese deugde van standvastigheid, orde, hardwerkendheid, spaarsamigheid, beskeidenheid en pligsgevoel.

Francke het ook 'n groot verandering bewerk ten opsigte van die tugtiging van kinders. Kinders is in sy tyd nog swaar en gewelddadig gestraf. Hy het die fisieke verminking van kinders grootliks gestop. Hy het die Duitsers oortuig dat 'n onderwyser kinders met voorbeeld en kennis moet beïndruk, hulle positief moet motiveer en vir hulle toeganklik moet wees. Hy het egter nog nie ingesien dat pouses en speel in kinders se belang is nie. As ontspanning het hy die skoolkinders in die groentetuine laat werk. Van die teoloë het hy verwag om naas leermeesters ook pastors vir die studente te wees. Hy was een van die eerste mense wat besef het dat teologiestudente intensiewe pastorale begeleiding nodig het (Obst 2013:114-120).

\section{Die professor}

Francke het sy opvoedkundige ideale self gepraktiseer. Hy was nie net leermeester nie, maar ook pastor en voog vir die 
teologiestudente. Aanvanklik was Francke filoloog. Hy het Grieks en Semitiese Tale gedoseer. In 1698 word hy egter as professor in teologie aangestel. Uit die staanspoor het hy homself as 'praktiese teoloog' verstaan. Sy lesings was 'vermanend' en 'praktyk-georiënteerd'. Hy het toegesien dat studente die lesings en studiemateriaal nie alleenlik verstaan nie, maar dit ook ter harte neem en daarvolgens gaan lewe.

Francke se lesings was toegespits op die aktuele kerklike situasie. Die kerklike probleme en uitdagings van daardie tyd is met die studente bespreek. Die lesings het ook uitgeloop op'n klomp praktiese werk in gemeentes en in die gemeenskap.

Tot groot teleurstelling van Francke moes hy op sy oudag agterkom dat die studente nie meer sy ideale steun nie. Bekerings en openbare getuienisse het hulle nie meer geïnteresseer nie. Belangstelling in die gemeenskapsprojekte het getaan. Hy moes met 'n skok ontdek dat talle studente in Halle kom studeer het weens die goeie onderrig in die tale en die talle beurse wat beskikbaar was. Die entoesiasme vir die Lutherse Piëtisme het, ongelukkig vir Francke, verdwyn (Obst 2013:120-123).

\section{Die ekonoom en organiseerder}

Om soveel sakebedrywe suksesvol in bedryf te hou, verg 'n goeie ekonoom en 'n organiseerder. Francke het die persoonlikheid gehad om hom met intelligente en visionêre ekonome te omring. Hy kon hulle oortuig om reuse finansiële bydraes te maak tot die weeshuis, die drukpers, uitgewery en Bybelgenootskap. Hierdie mense het hom gehelp om volhoubare finansieringsmodelle te ontwikkel wat hierdie instansies vir eeue in stand gehou het (Obst 2013:123-128).

\section{Die mens}

Daar bestaan slegs twee skilderye van Francke. Die eerste uit 1718 is in Augsburg geteken, en die tweede in 1725 in Berlyn deur die hofskilder Antoine Pesne, wat in kleur geskilder is. Op albei skilderye lyk Francke baie jonk. Volgens sy vrou, het hy jonk vertoon tot sy dood. Ten spyte van sy geweldige werklading was hy blykbaar nie 'n gespanne persoon nie. Hy was 'n kalm, rustige en saggeaarde mens. Hy was lief vir sy vrou en kinders, en hulle het hom verafgod. Vanselfsprekend was hy die vader van honderde weeskinders. Hulle het die grond aanbid waarop hy geloop het. Dit is nie verbasend nie dat hierdie man ná 300 jaar steeds een van Duitsland se grootste en mees geliefde persoonlikhede is. Selfs diegene wat teologies nie met hom kan saamstem nie, respekteer hom as een van Luther se grootste kinders. Wat hy vermag het, kon nog nooit weer nagedoen word nie (Obst 2013:128-135).

\section{Nalatenskap}

Francke het 'n reuse-nalatenskap. Minstens die volgende verdien vermelding: Die drukpers, boekhandel en die Bybelgenootskap (Cansteinische Bibelanstalt) het reeds tydens Francke se lewe 'n groot bydrae tot die literatuurskat van die Christendom gelewer. Francke se eie geskrifte (veral sy vroeë geskrifte) het danksy hierdie bedrywe behoue gebly. In 1724 word sy Son- en Feesdagpreke en in 1726 sy kategismuspreke gepubliseer. Later word sy vroeë voorlesings ook gepubliseer. Dit sluit die volgende in: Idea studiosi Theologiae (1712), Lectiones paraeneticae (1716), Praelectiones hermeneuticae (1717).

Die drukpers, in samewerking met die Bybelgenootskap, het veral gesorg vir die publikasie van bekostigbare pamflette, Bybelgedeeltes en volledige Bybels in Duits en ander vreemde tale. Noemenswaardig is die Tsjeggiese Bybel (1722) en die Poolse Bybel (1726), met eerste oplae van 10000 elk. Vanselfsprekend het Lutherse teoloë groot invloed op die vertaalprosesse gehad. Sendingpogings - onder andere in Indië - het ook met groot vrug van Francke se instellings gebruik gemaak. Sonder vertalings van Bybelgedeeltes is sending nie eens 'n denkmoontlikheid nie. Die vrug op die arbeid het meegebring dat 'n groot Bybelhuis in 1727 gebou moes word waar die groeiende personeelkorps gehuisves kon word. 'n Biblioteek was vanselfsprekend ook'n groeiende behoefte. In 1726 begin die bouwerk aan die reusebiblioteek, wat in daardie stadium reeds 18000 boeke moes huisves. Uit die staanspoor was die biblioteek 'n toeganklike ruimte, nie net vir dosente en studente nie, maar ook vir die belangstellende burgers.

Die weeshuis en die aangrensende groente- en vrugtetuine is vandag deel van UNESCO se wêrelderfenisgebiede. Die Franckesche Stiftungen bestaan uit ' $n$ universiteit met tientalle navorsingsinstitute. Die Fakulteit Teologie, Universiteit Halle, is een van Duitsland se trotse instellings. Talle beroemde persone het daar gestudeer en gedoseer, soos Friedrich Schleiermacher en Paul Tillich. Die Franckesche Stiftungen is deur die Kommunistiese bewind van die ou Oos-Duitsland totaal verwaarloos. Ná die val van die Berlynse muur het die destydse minister van buitelandse sake, Hans-Dietrich Genscher, vir Henry Kissinger en Michael Gorbatsjof na Halle geneem, met die bedoeling dat Amerika en Rusland moes help om Francke se nalatenskap in ere te herstel (Obst 2013:213). Vandag is die Universiteit van Halle en die Franckesche Stiftungen die trots van ou OosDuitsland - die hartland van die Lutherse Reformasie (vgl. Krenzlin 2004; Müller-Bahlke \& Baron 2013).

\section{Webskakels}

- https://de.wikipedia.org/wiki/August-HermannFrancke

- https://www.deutsche-digitale-bibliothek.de/ entity/11853-4688 (Werke van en oor Francke).

- https://gso.gbv.de/Francke (Werke van Francke).

- https://digital.francke-halle.de (Navorsingsprojekte oor, katalogusse en uitgawes van Francke se werke).

\section{Paul Tillich (1886-1965) \\ Lewe}

Lewensloop

- 1886 Gebore op 20 Augustus Starzeddel, Brandenburg.

- 1904 Voltooi sy matriekeksamen in Berlyn. 
- 1904-1912 Studeer teologie en filosofie in Berlyn, Tübingen en Halle.

- 1911 Behaal doktorsgraad in filosofie aan die Universiteit van Breslau.

- 1912 Voltooi sy teologiese studies in Halle-Wittenberg en word georden as predikant in die Lutherse Kerk. Tree dáár op as privaatdosent in teologie.

- 1914-1918 Militêre diensplig.

- 1914 Trou met Margarethe Wever van wie hy later skei.

- 1919-1924 Doseer godsdiensfilosofie in Berlyn.

- 1924 Trou met Hannah Wermer Gottschow.

- 1924 Doseer godsdiensfilosofie in Marburg.

- 1925 Ere-doktorsgraad deur die Universiteit van Halle.

- 1925 Doseer godsdiensfilosofie in Dresden en Leipzig.

- 1529 Doseer filosofie in Frankfurt.

- 1933 Emigreer na die VSA.

- 1933-1935 Doseer filosofiese teologie in New York.

- 1951 Eerste volume van sy Sistematiese Teologie word gepubliseer.

- 1955 Professor aan die Universiteit van Harvard.

- 1957 Tweede volume van sy Sistematiese Teologie word gepubliseer.

- 1962 Professor in teologie aan die Universiteit van Chicago.

- 1963 Derde volume van sy Sistematiese Teologie word gepubliseer.

- 1965 Sterf op 22 Oktober.

\section{Lewensverhaal}

Op 20 Augustus 1886 word Paul Johannes Oskar Tillich in Starzeddel in die omgewing van Guben in die provinsie Brandenburg gebore. Sy vader, Johannes Tillich, was daar die predikant van die Lutherse gemeente. Hy het sy moeder, Wilhelmina Mathilde Dürschen, op 'n jong ouderdom verloor en gevolglik word Paul Tillich sterk deur sy vader beïnvloed in sy grootwordjare.

Paul Tillich was maar vyf jaar oud toe sy vader aan die einde van die 19de eeu as dekaan in Schonfließ benoem word en die familie na Schönfließ, 'n dorpie in die Neumark, verhuis. Sedert 1898, vanaf sy 12 de tot sy 14 de lewensjaar, besoek Paul Tillich die gimnasium te Königsberg, Neumark. Vanaf 1901 besoek Paul Tillich die Friedrich-Wilhelms Gimnasium in Berlyn, en sedert 1900 woon die familie ook in Berlyn. Sy vader het daar ' $n$ amp in die koninklike Konsistorieraad beklee. As hoëre ampsdraer in die Brandenburgse Volkskerk moes hy onder andere teologiestudente in filosofie eksamineer. Vir Paul Tillich het dit die deur vir filosofiese gesprek met sy vader geopen. Sedertdien was dit sy wens om self 'n filosoof te word en het hy elke vrye oomblik benut om filosofiese literatuur te bestudeer.

In die herfs van 1904 voltooi Paul Tillich sy Abitur [die Duitse ekwiwalent van matriek], en daarna was dit 'n uitgemaakte saak dathy as die seun van'n ampsdraer in die Konsistorieraad van Pruise in die voetspore van sy vader sou volg en self predikant sou word. Gedurende die wintersemester van
1904-1905 word hy 'n ingeskrewe teologiestudent aan die universiteit in Berlyn, en buiten die teologiese lesings en seminare woon Tillich ook filosofie klasse by. As student verdiep Tillich hom in sy werk. Die paar skilderye en foto's uit sy studentedae getuig van 'n skugtere, teruggetrokke jong leerling in die filosofie wat nie kan perdry of veg nie. Gedurende sy eerste semester in Berlyn neem hy ook Hebreeus by Friedrich Delitzsch en filosofie by Adolf Lasson. Daarna volg 'n somersemester in Tübingen in 1905. In die wintersemester van 1905-1906 verwissel hy na Halle om teologie te studeer. Die Martin-Luther-Universität HalleWittenberg het die fondament gelê vir Tillich se Systematic Theology wat laat in sy lewe in die VSA gepubliseer sou word. Tillich was tot sy dood toe 'n Lutherse teoloog met 'n verpligting teenoor die Halle-tradisie.

In Oktober 1907 skryf Paul Tillich weer aan die Von Humboldt Universiteit van Berlyn in vir die wintersemester, maar voordat hy in die lente van 1909 sy eerste teologiese eksamen in Berlyn kon aflê, bied Ernst Klein, 'n predikant wat met sy vader bevriend was, aan dat Tillich hom in die klein plattelandse gemeente in Lichtenrade aflos. Ook sy eerste amptelike aanstelling as sogenaamde 'Lehrvikariat' in Nauen in 1911-1912 het nie vir Tillich 'n onderbreking in studie beteken nie. Tillich het homself op die tweede teologiese eksamen voor die Berlynse Konsistorieraad voorberei ten einde op 18 Augustus 1912 as predikant in die Brandenburgse Volkskerk opgeneem te word. Ook vir die voltooiing van sy doktorsgraad in filosofie, Die religionsgeschichtliche Konstruktion in Schillings positiver Philosophie, en sy doktorsgraad in die teologie, Mystik und Schuldbewußtsein in Schillings philosophischer Entwicklung, bly genoeg tyd oor.

Nadat Tillich in Desember 1911 sy eksamen vir sy Lizentiatengrad [by ons bekend as die proponentseksamen] aan die Universiteit Halle-Wittenberg afgelê het, is hy vanaf 1912 toegelaat om dáár teologiese voorlesings as privaatdosent aan te bied. In 1912 word hy hulppredikant in Berlyn-Moabit.

Sedert die somer van 1913 werk Tillich aan sy teologiese Habilitationschrift, maar in Augustus van 1914 breek die Eerste Wêreldoorlog uit. Nie minder nie as 93 Duitse intellektuele en onder hulle ook geëerde teoloë onderteken die 'verskriklike manifes', soos Karl Barth ([1913] 1976) daarna verwys, waarmeehulleopenlikmet die oorlogspolitiek van Kaiser Wilhelm II en sy kanselier, Bethmann Hollweg, assosieer. Aangesien Tillich hom ten tyde van die uitbreek van die oorlog in die hoofstad bevind, is hy nie in dieselfde posisie as Karl Barth om ' $n$ kritiese afstand te behou nie en meld hy aan as oorlogsvrywilliger. Hy dien van September 1914 tot September 1918 as veldpredikant in Frankryk. Tillich skryf dat hy na 'n paar maande van oorlogvoering daarvan oortuig was dat die oorlog wat langer as verwag geduur het, die ganse Europa sou vernietig. Hy erken ook dat die eenheid onder die klasse ' $n$ illusie blyk te wees. Totale neerslagtigheid en desperaatheid weerklink vanuit sy briewe vanaf die oorlogsfront (vgl. Tillich 1972:70). Hy verwys herhaaldelik weer na die sinneloosheid van die oorlog en na die lyke op 
die slagveld. Die oorlogslewe word ook in Tillich se godsdiensfilosofie weerspieël.

In 1919 publiseer Tillich tesame met Richard Wegener die boek Der Sozialismus als Kirchenfrage waarin die ingesteldheid van die Christendom jeens die samelewingsvorme in die algemeen, en sosialisme in die besonder, aan die orde kom. Die doelwit was uiteindelik om aan te toon dat die kerk te alle tye veronderstel is om 'n kritiese, profetiese afstand te handhaaf en dat die kerk nie sonder meer party kan trek vir sosialisme nie. Die kerk moet daarbenewens ook die verlore sosiale dimensie vir die Christendom, wat die verburgerlike kerk ten spyte van diakonale en missiologiese arbeid reeds lankal prysgegee het, herwin.

Nadat Tillich vanaf die oorlogsfront na Berlyn teruggekeer het, was daar in sy gemoed geen twyfel oor watter loopbaan hy sou volg nie. Hy skryf in 1917 aan sy vader dat hy homself as professor in die teologie sien, en hy aanvaar vervolgens 'n pos aan die Berlynse Fredrich Wilhelmsuniversiteit as privaatdosent. In die somersemester van 1919 bied hy ' $n$ voorlesingsreeks aan met die tema Das Christentum und die Gesellschaftsprobleme der Gegenwart [Die Christendom en die maatskaplike probleme in die hede]. Daarbenewens gee Tillich aandag aan die godsdienstige en filosofiese fondamente van politieke strominge. In die wintersemester van 19191920 volg 'n Enzyklopädie der Theologie und Religionswissenschaft und Religion und Kultur (Ensiklopedie van die teologie en die godsdienswetenskap en Godsdiens en kultuur. Tillich se akademiese inset in Berlyn dui daarop dat sy lewe tegelykertyd intensiewer en ekstensiewer geword het. Afgesien van die geestelike en liggaamlik 'knak' wat Tillich op die oorlogsfront opgedoen het, keer hy as veranderde man terug. Die skugtere, teruggetrokke, altyd studerende seun het 'n man geword wat die veelvoud van kulturele en maatskaplike aanbiedinge wat die rykshoofstad gebied het, aanneem en krities ondersoek.

Deelname aan die Berlynse kunstoneel beteken vir die konserwatief opgevoede en aan 'n enge morele maatstaf gebonde predikantseun van Pruise, 'n bevryding. Op 'n Berlynse maskerbal in Februarie van 1920 ontmoet Paul Tillich die 24-jarige Hannah Werner, 'n kuns-onderwyseres aan die Berlynse Neukölln, met wie hy op 22 Maart 1924 getroud is nadat hy van Margarete Wever geskei is.

Aan die begin van die somersemester in 1924 word Paul Tillich buitengewone professor in Sistematiese Teologie aan die Hessiese Philippsuniversiteit in Marburg en maak daarmee gewisse vordering in sy akademiese loopbaan. Dit was egter vir hom en sy vrou, Hannah, 'n moeilike skuif vanaf die kultureel aktiewe en glansryke metropool na die landelike universiteitstad, en derhalwe het albei dit eintlik maar as 'n deurgangstyd beskou. Gedurende sy drie semesters in Marburg ervaar Tillich die radikale uitwerking van die nuwe ortodoksie (van Karl Barth) op teologiestudente. Dit is vir Tillich ontstellend dat die teologiese denke afskeid geneem het van kulturele vraagstukke, dat teoloë soos Schleiermacher, Von Harnack, Troeltsch en Otto verag en verwerp word, en dat politiek uit die teologiese gesprek verban is. Daarom, toe die moontlikheid van 'n beroep as godsdienswetenskaplike professsor na die Technische Hochschule Dresden hom voordoen, het Tillich nie gehuiwer nie. Die ruimtelike en kulturele openheid van die groot stad het hom aangespreek, en Dresden was die middelpunt van die beeldende kuns. Daar kon Tillich in aanraking kom met skilderkuns, argitektuur, uitvoerende kuns en opera. Tillich het pas met die aanvang van die wintersemester in 1925-1926 voorlesingstemas soos die intellektuele geskiedenis van die Protestantisme aangekondig, toe die Universiteit Halle-Wittenberg bekend gemaak het dat Tillich met ' $n$ eredoktorsgraad vereer gaan word vir sy skerpsinnigheid en die dialektiese behendigheid waarmee hy'n godsdiensfilosofiese program ontwikkel het en in die raam van ' $n$ algemeen wetenskaplike leerplan ingevoer het. Dit het daartoe gelei dat die akademiese jeug filosofie en samelewing met godsdiens kon verbind en navorsing oor hierdie samehange kon bevorder. As gevolg van sy werksaamheid in Dresden kon Tillich gedurende die wintersemester van 1927-1928 as professor in die sistematiese teologie ook voorlesings by die Universiteit van Leipzig aanbied.

Aan die begin van 1928 ontmoet Tillich die filosoof Max Scheler tydens ' $n$ internasionale kongres in Crissier. Scheler het ' $n$ pos aan die Universiteit van Frankfurt beklee, maar hy sterf op 19 Mei 1928 op 54-jarige ouderdom. Daarmee gaan daar toe vir Tillich ' $n$ beroep aan die modernste en mees liberale universiteit in Duitsland oop. Daar het in daardie stadium nog geen teologiese fakulteit aan dié Universiteit bestaan nie, maar vir Tillich was dit geen probleem nie, aangesien sy voorlesings op die grens tussen teologie en filosofie beweeg het en hy vir die talryke filosofiestudente 'n ervaring van die vak gebied het, wat ook betrekking op die eksistensiële het. As 'n mens wat 'n hoë premie plaas op geselligheid en lewendige persoonlike kruisbestuiwing, vind Tillich in Frankfurt vele aanknopingspunte met onder andere die sosioloog Karl Mannheim, die geskiedkundige Ernst Kantorowicz, die neuroloog Kurt Goldstein, die sielkundige Adhemer Gelb en die Joodse godsdienswetenskaplike Martin Buber. Tillich handhaaf ook enge betrekkinge met die Frankfurter Institut für Sozialforschung en lewer veral 'n bydrae ten opsigte van die Marx-resepsie en -kritiek. Hier werk hy ook nou saam met Max Horkheimer, vir wie hy in 1930 'n pos in sosiologie aan die Universiteit in Frankfurt moontlik maak.

Tydens die opkoms van Adolf Hitler in Duitsland, en weens die feit dat talle kerklike teoloë Hitler se teorieë oor ras met die Bybelse skeppingsleer verdedig het, het Tillich skerp gereageer met die siening dat so 'n regverdiging van nasionalisme en rasse-ideologie die kerk se profetiese stem ondergrawe en die kerk se opdrag om getuie vir alle nasies te wees, verraai. Op 01 April 1933 word die Jode-boikot oor die gesamentlike Ryksgebied afgekondig, wat die lewe vir Joodse sakelui, dokters en regsgeleerdes onmoontlik gemaak het, maar dit het ook nie-Jode geraak, en so word Tillich uit sy pos aan die Universiteit van Frankfurt onthef. Toevallig het die Amerikaanse teoloog Reinhold Niebuhr Tillich in die somer van 1933 uitgenooi om as gasprofessor filosofiese voorlesings 
aan die Columbia-universiteit en die Union Theological Seminary in New York te lewer. Toe Tillich egter op 03 November 1933 met sy vrou, Hannah, en sy dogter, Erdmuthe, in New York voet aan wal sit, het hulle nie besef hoe ingrypend hulle lewens sou verander nie. Tillich moes Engels bemeester. Hy kon dit maklik lees, maar dit was moeilik om te volg en uiters moeilik om te praat. Deur sy kontak met Reinhold Niebuhr en Wilhelm Pauck het Tillich egter toegang tot die kulturele, wetenskaplike en ook publikasie-organe van die VSA verkry. Uiteindelik bring Tillich meer as 20 jaar in New York deur, en doen hy 'n bykans ensiklopediese kennis op oor teologies-geesteswetenskaplike, polities-maatskaplike, tegniese, natuurwetenskaplike en psigologiese sake, en oor verskillende kunsvorme. Sy studentegetalle het oor die jare toegeneem, hoewel sommige oor die moeilik verstaanbare Duitse professor gekla het. Ver verwyder van die Amerikaanse pragmatisme, moedig Tillich kritiese denke aan. Emigrasie was vir hom ' $n$ intense ervaring, en hy merk in 'n radioonderhoud in 1962 op dat hy nóg Amerika nóg Duitsland as sy tuiste beskou, maar dat hy soos 'n swerwer tussen twee wêrelde voel. Sedert sy aankoms in die VSA het Tillich baie landgenote ontmoet wat deur dieselfde lot as hy getref is. So word in New York in die huis van Else en Hans Staudinger die gedagte vir eiehelp vir Duitse emigrante gebore. Hierdie inisiatief het oor ' $n$ tydperk van twee jaar meer as \$17 000 aan ongeveer 600 emigrante-huisgesinne uitgedeel. Dit was vir die Duitsers belangrik om aan te toon dat hulle in die VSA selfonderhoudend kan wees. Dit het ook nie lank geduur nie voor Tillich ook in die VSA vereer is vir sy arbeid. In 1940 ontvang hy van Yale die graad Doctor of Sacred Theology. Sedert die herfs van 1955 is Tillich professor aan die Harvarduniversiteit, maar omdat Tillich reeds afgetree het, moes die aanstelling van jaar tot jaar hernu word - tot 1961 is dit ses maal hernu. Op 75-jarige ouderdom het die onweerstaanbare aanbod om aan die Universiteit van Chicago te doseer, hom te beurt geval. Sy voorneme was om in 1966 op 80-jarige ouderdom as professor by die New School for Social Research in New York te begin, maar op 22 Oktober 1965 het hy in die Universiteitskliniek in Chicago gesterf.

Hoewel Tillich nooit permanent na Duitsland terugkeer nie, aanvaar hy in 1956 op 70-jarige ouderdom vir twee jaar 'n gasdosentepos in Hamburg. Een en dertig jaar na die eredoktorsgraad wat deur die Universiteit Halle-Wittenberg aan hom toegeken is, word Tillich ook eredoktor van die Vrye Universiteit van Berlyn. In 1958 verwerf hy ook die Goetheprys in Hamburg. ${ }^{1}$

\section{Teologiese bydrae}

Die Amerikaanse Lutheraan Martin E Marty het van Paul Tillich gesê dat daar na die Tweede Wêreldoorlog geen Protestantse teoloog was wat meer begaafd was of wat aan die universiteit meer aansien geniet het nie. Sy tekste is wyd gelees, en te midde van 'n sekulêre tydgleuf het sy persoonlikheid en sy invloed onder studente en professore 'n verhoogde belangstelling in teologiese vrae gewek. As 1.Vir omvattende biografiese inligting kan gekyk word na Wehr (1979) en Schüßler en Sturm (2015) daar ooit 'n teoloog was wat met sy werk as brugbouer tussen teologie en ander dissiplines en ook as apologeet beskou kon word, dan is dit Paul Tillich.

Wat die verhouding tussen die teologie en die natuurwetenskap betref, is Tillich van mening dat die natuurwetenskap die menslike verstand die geleentheid bied om al die teenstrydighede, hulle wedersydse betrekkinge en hulle funksionering te omhels. In die teologie, daarenteen, ontmoet die mens op omvattende wyse dit wat aan die lewe sin gee en dit wat die mens noodwendig en uiteindelik ten diepste raak. Die terreine van die natuurwetenskap en die teologie oorvleuel, maar staan nie in konflik met mekaar nie. Konflik ontstaan alleen wanneer die onderskeide tussen die verskillende dimensies nie deur albei kante eerbiedig word nie (Tillich1972:391).

Vir Tillich was dit op bykans elke lewensterrein sy lotsbeskikking om op die grens van twee bestaansmoontlikhede te staan sonder om volledig binne een tuis te voel en sonder om finaal ' $n$ beslissing teen die een of die ander te vel. Net so vrugbaar as wat hierdie ingesteldheid vir denke is, want denke veronderstel 'n openheid vir nuwe moontlikhede, net so moeilik en selfs gevaarlik is dit vir die lewe wat voortdurend 'n besluit vir die een en teen die ander vereis. Om so op die grens te bestaan, is vol spanning en beweging. Dit beteken dat 'n mens nooit stilstaan nie, want die grens word voortdurend oorgesteek, en dan word daar weer teruggekeer - voortdurend heen en weer. Die uitdaging is om op die grens 'n plek te skep waar 'n mens wel vir 'n tyd lank kan vertoef, sonder om weer deur 'n afgrensing ingeperk te word (Tillich1972:420). Die mens het egter altyd binne homself ' $n$ begrensdheid en 'n eindigheid, en dit is vir 'n eindige wese onmoontlik om die grens na die oneindige oor te steek; die oneindige kan wel die grens na die eindige oorsteek.

Vir Tillich was die menslike eksistensie veel belangriker as om uitsprake oor die menslike syn te maak, en dit beteken dat hy van konkrete lewensituasies bewus was en sy tydgenote daarvan bewus gemaak het. Dit gaan vir Tillich by uitstek oor die 'Dasein'.

Teologie is volgens Tillich 'n funksie van die Christelike kerk en moet daarom aan die vereistes van die kerk voldoen. Die kerk is verder ook 'n nuwe vorm van syn in 'n gemeenskap wat deur die Heilige Gees in aansyn geroep word. Hierbinne moet teologie beoefen word wat die waarheid van die Christelike boodskap verkondig, en hierdie waarheid moet vir elke nuwe generasie nuut verwoord word. Teologie beweeg altyd binne die spanning tussen twee pole: die ewige waarheid van sy fondament, en die tydsituasie wat binne hierdie waarheid opgeneem moet word. Daarvoor is apologetiese teologie nodig om die vrae wat die situasie stel, te kan beantwoord met die mag van die ewige boodskap.

Christelike teologie word begrond op die eienaardige uitkoms: Jesus Christus bly ten spyte van sy oneindigende 
betekenis in sy konkreetheid die norm vir elke religieuse ervaring. Hierdie uitkoms gaan die religieuse ervaring vooraf en word nie daaruit afgelei nie. Daarom is die skeppende krag van die ervaring ook in Jesus Christus begrond en nie in die ervaring self nie (Tillich 1958a:57). Daarbenewens bepaal metode en sisteem mekaar wedersyds. Tillich beskou die metode as korrelasie: Dit handel oor ' $n$ metode wat vasgestel is vanuit die feit dat die inhoude van die teologiese uitsprake in 'n baie spesifieke verhouding tot die mense aan wie dit gerig is, moet staan. Dit beteken dat teologie nie kan stol in universeel-geldende geloofsuitsprake nie, maar dat teologie altyd verbinding met en relevansie tot die hede moet soek. Daarom bepleit Tillich 'n korrelasie tussen die vrae van die hede en die boodskap van die evangelie. Teologie moet uiteindelik menslike bestaan en Goddelike selfopenbaring met mekaar laat korreleer (Tillich1958a:15). Teologie formuleer die vrae wat in die menslike eksistensie na vore kom, en die teologie formuleer die Goddelike selfopenbaring in die rigting van hierdie vrae. Dit beteken dat die teologie ook die menslike eksistensie in sy huidige situasie ernstig behoort op te neem. Dan kan die antwoorde wat die teologie op hierdie spesifieke vrae bied ontsluit word, sodat die vervreemde, lydende, soekende en ontmoedigde mens daardeur bemoedig kan word. Gevolglik word God die oneindige Mag, wat die bedreiging van die 'niks' weerstaan. Wanneer die begrip 'koninkryk van God' in verbinding met die misterie van ons menslike bestaan verstaan word, word die 'koninkryk van God' die sin, die vervulling van die eenheid van die geskiedenis. Tillich veronderstel ' $n$ wisselwerking tussen die teologiese bronne en die eksistensiële vraagstukke van die dag. Gevolglik reken Tillich ook dat 'n teoloog nie 'n teoloog is indien hy nie die filosofie ernstig opneem nie. Tillich herwaardeer in hierdie opsig Johannes Calvyn se insig van 'n samehang tussen selfkennis en kennis van God.

Indien die historiese navorsing van die Bybelwetenskappe die onderskeid tussen die historiese, legendariese en die mitiese elemente in die Evangelies vasstel, bied die sistematiese teologie die voertuig waardeur die Christelike simbole in die Bybel geïnterpreteer kan word (Tillich1958b:119). Dit is immers nie die historiese Jesus wat die 'nuwe syn' tot stand gebring het nie, maar die histories onbewysbare paradoks van Christus wat alleen deur die geloof toeganklik word, wat die Bringer en die Draer van die 'nuwe syn' word deurdat dit in die woorde, dade en lyding van Jesus Christus manifesteer. Hierdie 'nuwe syn' manifesteer in ' $n$ bestaan gekenmerk deur die mag van die liefde, die gawe van vryheid, en vervullende geluk. Die totale universum is nie meer onder die wet aan die dood onderworpe nie, maar aan ' $n$ hoër wet van die ewige lewe. So behoort hoop tot die oorspronklike krag van die menslike syn wat hom begelei as drywende krag van die totale menslike 'Dasein'. Wat die werking van die Heilige Gees betref, beskou Tillich die menslike gees as 'n dimensie van die eindige mens wat deur die werking van die Gees van
God tot selftransendering gedryf word. Die Gees van God word dus in die fisieke dimensie geaktualiseer (Tillich1966:142).

\section{Werke}

1. Systematische Theologie

Band I: Deel 1: Vernunft und Offenbarung a. Deel 2: Sein und Gott

Band II: Deel 3: Die Existenz und der Christus

Band III: Deel 4: Das Leben und der Geist

b. Deel 5: Geschichte und Reich Gottes

2. Gesammelte Werke

Band I Frühe Hauptwerke

Band II Christentum und soziale Gestaltung

Frühe Schriften zum Religiösen Sozialismus

Band III Das religiöse Fundament des moralischen Handelns

Schriften zur Ethik und zum Menschenbild

Band IV Philosophie und Schicksal

Schriften zur Erkenntnislehre und Existenzphilosophie

Band V Die Frage nach dem Unbedingten Schriften zur Religionsphilosophie

Band VI Die Widerstreit von Raum und Zeit Schriften zur Geschichtsphilosophie

Band VII Der Protestantismus in Kritik und Gestaltung Schriften zur Theologie I

Band VIII Offenbarung und Glaube Schriften zur Theologie II

Band IX Die religiöse Substanz der Kultur Schriften zur Theologie der Kultur

Band $X \quad$ Die religiöse Deutung der Gegenwart Schriften zur Zeitkritik

Band XI Sein und Sinn Zwei Schriften zur Ontologie und Ethik

Band XII Begegungen: Paul Tillich über sich selbst und andere

Band XIII Impression und Reflexion: Ein Lebensbild in Aufsätzen, Reden und Stellungnahmen

Band XIV Bibliographie, Register und Textgeschichte der Gesammelten Werke

3. Ergänzungs- und Nachlaßbände zu den Gesammelten Werken

Band I Vorlesungen über die Geschichte des christlichen Denkens: Teil

1: Urchristentum bis Nachreformation

Band II Vorlesungen über die Geschichte des christlichen Denkens: Teil

2: Aspekte des Protestantismus im 19. und 20. Jahrhundert

Band III An meine Deutsche Freunde: Die politischen Reden Paul Tillich's während des 2. Weltkriegs

Band IV Korrelation: Die Antworten der Religion auf Fragen der Zeit 
4. Die religiösen Reden

1. Folge In der Tiefe ist Wahrheit

2. Folge Das Neue Sein

3. Folge Das Ewige im Jetz

\section{Auswahlbände}

Auf der Grenze: Aus dem Lebenswerk Paul Tillichs. (1962). Der Mensch zwischen Bedrohung und Gebrogenheit.

\section{Erkenning \\ Mededingende belange}

Die outeurs verklaar dat hulle geen finansiële of persoonlike verhouding(s) het wat hulle op 'n voordelige of nadelige wyse by die skryf van die artikel beïnloed het nie.

\section{Outeursbydrae}

I.W.C.v.W. het die gedeelte oor Francke nagevors en geskryf, terwyl E.1.R. die gedeelte oor Tillich nagevors en geskryf het.

\section{Literatuurverwysings}

Barth, K., [1913] 1977, Predigten 1913, G. Sauter \& H. Stoevesandt (Hrsg.), Theologischer Verlag, Zürich. (Karl Barth Gesamtausgabe, Bd. 8).

De Groot, C.G., 1992, Spener en Francke: Grondleggers van die Duitse Piëtisme, Instituut vir Reformatoriese Studies, Potchefstroom. (Reeks F2, Nommer 55).

Hauschild, W.-D., 1999, Lehrbuch der Kirchen- und Dogmengeschichte, Band 2, Reformation und Neuzeit, Gütersloher Verlagshaus, Gütersloh.

Krenzlin, U., 2004, Francke-Denkmal: Franckesche Stiftungen ze Halle, Verlag Schnell \& Steiner, Regensburg.

Müller-Bahlke, T. \& Baron, E., 2013, A guided walk through the Francke Foundations, Verlag der Franckeschen Stiftungen zu Halle, Halle.

Obst, H., 2002, A.H. Francke und die Franckeschen Stiftungen in Halle, Vandenhoeck, Göttingen. (Kleine Reihe V\&R 4030).

Obst, H., 2013, August Hermann Francke und sein Werk, Verlag der Franckeschen Stiftungen zu Halle, Halle.

Schüßler, W. \& Sturm, E., 2015, Paul Tillich: Leben - Werk-Wirkung, Wissenschaftliche Buchgesellschaft, Darmstadt.

Tillich, P., 1958a, Systematische Theologie Band I, Evangelische Verlagswerk, Stuttgart.

Tillich, P., 1958b, Systematische Theologie Band II, Evangelische Verlagswerk, Stuttgart.

Tillich, P., 1966, Systematische Theologie Band III: Das Leben und der Geist, Die Geschichte und das Reich Gottes, Evangelische Verlagswerk, Stuttgart.

Tillich, P., 1972, Gesammelte Werke Band XIII: Impressionen und Reflexionen, Evangelische Verlagswerk, Stuttgart.

Wehr, G., 1979, Paul Tillich in Selbstzeugnisse und Bilddokumenten, Rowohlt, Hamburg. 